\title{
Athelium imperceptum Nyl. (Thelocarpaceae, Ascomycota), a scarcely known ephemeral lichen of biological soil crusts, new to Ukraine
}

\author{
AlEXANDER YeVGENOVICH KHODOSOVTSEV \\ ANNA OLEKSIIVNA NAUMOVICH \\ OLGA SERGEEVNA VONDRÁKOVÁ \\ JAN VONDRÁK
}

ХодОСовцев А.Є., НАУмОвИЧ Г.О., ВоНДРАКОВА О.С., ВОНДРАК Я., 2010: Athelium imperceptum Nyl. (Thelocarpaceae, Ascomycota) - маловідомий ефемерний лишайник $з$ грунтової біологічної кірки, новий для України. Черноморск. бот. ж., T. 6, N 3: 385-389.

Обговорюються результати дослідження рідкісного лишайника Athelium imperceptum
(syn. Thelocarpon imperceptum) знайденого вперше в Україні. Представлені данні
щодо екології виду, його поширення у Європі, а також сучасний діагноз роду
Athelium та виду Athelium imperceptum. Відновлений рід Athelium відрізняєтся від
Thelocarpon відсутністю пульвінової кислоти та ії похідних, які утворюють
жовтувату поволоку на поверхні плодових тіл. Структура перитеція нагадує таку у
Thelopsis rubella. Thelocarpon magnussonii не утворює пульвінової кислоти та ії
похідних (вірогідно вторинно втрачених), однак відрізняється від Athelium
imperceptum добре розвинутим сланевим краєм.

Ключові слова: Athelium imperceptum, Kelleria polyspora, біологічна грунтова кірка, Thelopsis, Thelocarpon, Україна

Khodosovtsev A.Ye., Naumovich A., Vondráková O.S., Vondrák J., 2010: Athelium imperceptum Nyl. (Thelocarpaceae, Ascomycota), a scarcely known ephemeral lichen of biological soil crust, new to Ukraine. Chornomors k. bot. z., Vol. 6, N 3: 385-389.

Our new record to Ukraine of a rare lichen Athelium imperceptum (syn. Thelocarpon imperceptum) is discussed. We provide data on ecology of the species and its European distribution and we have also made up modern diagnoses of both, the genus Athelium and the species A. imperceptum. The recovered genus Athelium is distinguished from Thelocarpon by the absence of pulvinic acid derivates forming a superficial yellow pruina on perithecia; its perithecia rather resemble those of Thelopsis rubella. Thelocarpon magnussonii is also devoid of yellow pruina (probably a secondary lost) but it differs from A. imperceptum by its well-developed thalline exciple.

Keywords: Athelium imperceptum, Kelleria polyspora, biological soil crust, Thelopsis, Thelocarpon, Ukraine

ХОДОСОвЦЕв А.Е., НАУМОвИЧ А.О., ВОНДРАКОвА О.С., ВОНДРАК Я., 2010: Athelium imperceptum Nyl. (Thelocarpaceae, Ascomycota) - малоизвестный эфемерный лишайник из почвенной биологической корки, новый для Украины. Черноморск. бот. ж., Т. 6, N 3: 385-389.

Обсуждаються результаты исследования редкого лишайника Athelium imperceptum (syn. Thelocarpon imperceptum) найденного впервые в Украине. Представлены данные об экологии вида, его распространении в Европе, а также современный диагноз рода Athelium и вида Athelium imperceptum. Восстановленный род Athelium отличается от Thelocarpon отсутствием пульвиновой кислоты и ее производных, образующих желтоватый налет на поверхности плодовых тел. Структура перитеция также напоминает таковую у Thelopsis rubella. Thelocarpon magnussonii не образует

(C) A.Ye. Khodosovtsev, A. Naumovich, O.S. Vondráková, J. Vondrák Чорноморськ. бот. ж., Т. 6, № 3: 385-389. 
пульвиновой кислоты и ее производных (вероятно вторично утраченных), однако отличается от Athelium imperceptum хорошо развитым слоевищным эксципулом.

Ключевые слова: Athelium imperceptum, Kelleria polyspora, биологическая почвенная корка, Thelopsis, Thelocarpon, Украина

\section{Introduction}

During the short winter excursion to south Ukrainian steppes (2009), we collected a greenish biological crust on soil in a disturbed grassland. The crust was covered by colourless perithecia of Athelium imperceptum (syn. Thelocarpon imperceptum), an ephemeral lichen, which had never been collected in Ukraine before. Since its discovery by NYLANDER [1886], the species was only found several times in Europe. Fructification of $A$. imperceptum is probably restricted to cold months of the year, because our attempts to find it again in the same locality in the summer of the next year failed. Nevertheless, perithecia of $A$. imperceptum were visible again in the next winter. We found another Ukrainian locality in winter 2010 / 2011. We consider A. imperceptum as an outstanding little-known species and provide its modern description and summarize known data on its ecology and distribution.

\section{Material and Methods}

Samples were collected in winters $(2009,2010)$ in southern Ukraine (Kherson region). Specimens are deposited in herbaria KHER and CBFS. Following characters were used for description of our material: thallus structure, size and colour of perithecia, thickness and structure of ascoma wall, direction and length of periphyses, structure of hamathecium, size, shape and I-reaction of mature asci, size and shape of ascospores and number of ascospores per ascus. Observations and measurements were done in water, to an accuracy of $0.25 \mu \mathrm{m}$ for ascospore dimensions, $10 \mu \mathrm{m}$ for sizes of perithecia and $1 \mu \mathrm{m}$ for other characters. Measurements are given as (min.-) $\mathrm{X} \pm \mathrm{SD}$ (-max.), where $\mathrm{X}=$ mean value and $\mathrm{SD}=$ standard deviation. Numbers of measurements are given in square parentheses [n]. Morphological terminology follows SMITH et al. [2009].

\section{Results and discussion}

ATHELIUM Nyl., Flora, Jena 69: 463 (1886).

Short diagnostic description: Ascomata perithecia. Wall of perithecia \pm colourless, of narrow hyphae. Asci I+ light blue, with thin tholus, multispored ( $>100$ spores per ascus). Ascospores simple. Hymenial gel I-. Periphyses present, c. 20-30 $\mu \mathrm{m}$ long, perpendicular to upper perithecial wall, simple to branch. Paraphyses absent.

Athelium is a monotypic genus; the only species, A. imperceptum, is characterized below.

ATHELIUM imperceptum Nyl., Flora, Jena 69: 463 (1886).

Type: Supra terram muri humidi prope Zuerich in Helvetia, [coll.] Hegetschweiler (WA? typus, not seen).

$\equiv$ Thelocarpon imperceptum (Nyl.) Mig., Flora von Deutschl., 2, 12: 485 (1926); Thelococcum imperceptum (Nyl.) H. Magn., Rabh., Krypt.-Fl., 9, 5 (1): 289 (1935).

= Thelococcum polysporum Tomin, Opredelitel Korkovich Lishainikov Europ. Chasti SSSR: 303 (1956).

Type: Russia. Volgograd, near Krasnoarmeysk (Sarepta) town, 09.1922, V.A. Keller (LE 294 - isotypus).

三Kelleria polyspora Tomin., Über die Bodenflecht. Der Halbwüst. Süd-Ost-Russl.: 28 (1926) (illegitimate name, Art. 53.1); Thelocarpon polysporum (Tomin) Tomin, Opredelitel Korkovich Lishainikov Europ. Chasti SSSR: 303 (1956) (illegitimate name); Thelocarpon imperceptum var. polysporum (Tomin) Oxner in Kopachevskaya, Makarevicz et Oxner, Hadbook of the lichens of the USSR, 4, Verrucariaceae - Pilocarpaceae, Leningrad: 111 (1977) (illegitimate name). (Fig. 1.). 
Images of the CBFS specimen are available on: http://botanika.bf.jcu.cz/lichenology/index.php.
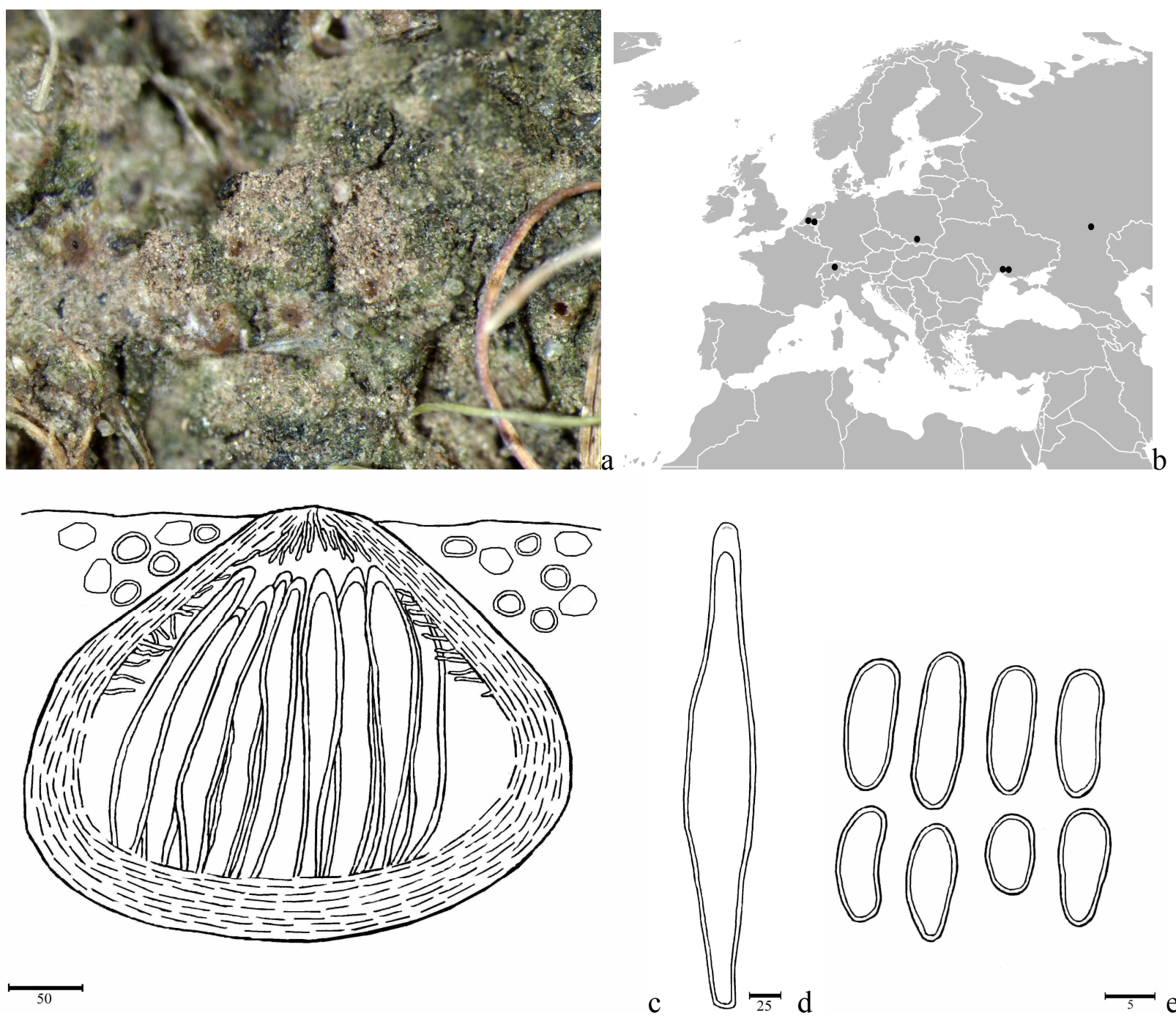

Fig. 1. Athelium imperceptum: a - thallus with perithecia immersed in the soil (CBFS JV6946); b - known distribution; $\mathbf{c}$ - vertical section of a perithecium; $d$ - ascus; $\mathbf{e}-\operatorname{ascospores}($ scales in $\mu \mathrm{m})$.

Рис. 1. Athelium imperceptum: a - слань 3 перитеціями заглибленими у грунт (CBFS JV6946); b відоме поширення; с - вертикальний зріз через перитецій; d - сумка; e - аскоспори (мірило у $\mu \mathrm{m})$.

Thallus very thin, film-like, inconspicuous when dry but forming greenish spots when wet; $\mathrm{K}-, \mathrm{C}-, \mathrm{P}-, \mathrm{I}-, \mathrm{UV}-$ (or UV+ indistinctly yellowish). Thallus hyphae c. $0.5-0.75 \mu \mathrm{m}$ wide, forming a loose network among soil particles in lower part and enclosing chlorococcoid algae in upper part. Algal cells (10-) $17.4 \pm 6$ (-30) $\mu \mathrm{m}$ diam. [15]. Perithecia (250-) $330 \pm 65$ $(-420) \mu \mathrm{m}$ diam. [10], globose in section, fully to three quarters immersed in soil crust; ostiolar areas only visible as pale yellow / pale brownish spots c. 100-200 $\mu \mathrm{m}$ diam. Ascoma wall gelatinous, colourless or pale rose-brownish, (35-) $43 \pm 6(-50) \mu \mathrm{m}$ wide [10], not differentiated in layers, of narrow hyphae, c. 0.5-0.75 $\mu \mathrm{m}$ wide, $\mathrm{K}-$, $\mathrm{C}-$, $\mathrm{P}-$, I-. Periphyses (20-) $27 \pm 4(-35) \mu \mathrm{m}$ long [15], single or sometimes branched, perpendicular to the uppermost wall of perithecium. Paraphyses absent. Hymenial gel I-. Asci I+ light blue, multispored (200-300 spores per ascus), (180-) 260 $\pm 40(-320) \times(25-) 40 \pm 10(-60) \mu \mathrm{m}[15]$. Ascospores simple, colourless, with one oil drop in their centers, bacilliform, with variable

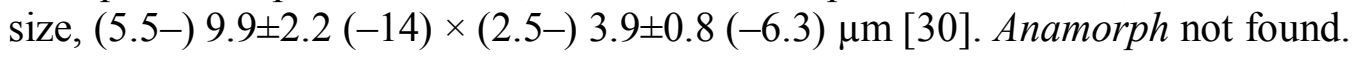


Ecology. It is a little collected inconspicuous lichen (probably very rare, but maybe largely overlooked) and data on its ecology are sparse. According to our observations of the south Ukrainian population, its lichenized thalli and perithecia are probably ephemeral, restricted to moist and cold seasons. South Ukrainian samples were collected in dry disturbed grasslands on a flat southern slopes. In Poland, it was collected on disturbed soil in zinc and lead enriched anthropogenic substrates [BIELCZIK et al., 2009]. In the Netherlands, it was found in two rural sites on loamy soil together with Collema limosum and respectively Verrucaria sp. [VAN DEN BOOM et al., 2000]. In Russia, it was collected on soil in open natural steppe [ТОМин, 1926].

Distribution. (Fig. 1b). Known only from Europe; Russia [Томин, 1926], Poland [BIELCZYK et al., 2009], The Netherland [VAN DEN BOOM, 2000], Switzerland [NYLANDER, 1886]. New to Ukraine.

Ukrainian samples. Kherson region, Bilozers'ky district, village Mykils'ke, right bank of Ingulets river, on disturbed soil near concrete plate, alt. $12 \mathrm{~m}, \mathrm{~N} 46^{\circ} 43^{\circ} 02.7^{\prime \prime} \mathrm{E}$ 3248`51.2", 7 Feb. 2009, J. Vondrák, A. Khodosovtsev, A. Naumovich (KHER, CBFS JV6946); Ibid.: 28 Feb. 2010, A. Khodosovtsev (KHER); vill. Sofievka, alt. $22 \mathrm{~m}$, 4635 55.4“' E 32¹4`13.2”, 13 Feb 2011, A. Khodosovtsev, Yu. Khodosovtseva (KHER).

Remarks. This species, recently named Thelocarpon imperceptum, is distinguished from other Thelocarpon species (except for T. magnussonii G. Salisb. [ORANGE et al., 2009]) by entire absence of pulvinic acid derivates (vulpinic acid, pulvinic dilactone and pulvinic acid) forming a superficial yellow pruina. We prefer to place $T$. imperceptum into the separated genus Athelium, because of its outstanding morphology, mainly its colourless perithecia without yellow pruina. Perithecia of Thelocarpon magnussonii are also without yellow pruina, but this species has distinct thalline exciple and is similar to other Thelocarpon species with thalline exciple and pruinose perithecia; we assume secondary absence of yellow pruina in T. magnussonii.

Telococcum polysporum (= Kelleria polyspora, illegitimate name) was described on morphologically \pm identical specimen to those of $A$. imperceptum, but with smaller ascospores $(6-9 \times 3-3.5 \mu \mathrm{m})$ [ТОМИН, 1956]; NYLANDER [1886] observed 7-10 $\times 4-4.5 \mu \mathrm{m}$. On grounds of our observations, sizes of ascospores considerably vary in our specimens of $A$. imperceptum; some asci may contain only small ascospores $(4-6 \times 3-5 \mu \mathrm{m})$. We consider $T$. polysporum a later synonym to $A$. imperceptum.

Some species of the genus Thelopsis (Stictidaceae with doubts), e.g. T. rubella Nyl., have very similar morphology of perithecia to Athelium [ROSE et al., 2009]; colourless perithecia without pruina, multispored asci, long periphyses, I-reactions of asci and hymenial gel, etc. In the other hand, Thelopsis differs from Athelium in mostly septate ascospores, Trentepohlia photobiont and presence of simple paraphyses.

Other two genera, 1) Sarcosagium (Thelocarpaceae) and 2) Thelocarpella (Thelocarpaceae) differ from Athelium mainly by 1) fully exposed apothecial ascomata with white-pink pruina [GILBERT, PURVIS, 2009] and 2) dark pigmented to carbonized upper wall of perithecia [NAVARRO-ROSINÉS et al., 1999].

We consider Athelium imperceptum most closely similar to the genus Thelopsis but future molecular studies will show us the real phylogenetic affinity of this peculiar species.

\section{Literature}

Томин М.П. Почвенные лишайники. Лишайники, встречающиеся на солонцеватых почвах в полупустынной области Юго-Востока // Растительный мир русских степей, полупустынь и пустынь. Очерки экологические и фитосоциологические. - Воронеж, 1926. - Вып. 2. - С. 19-24. 
Athelium imperceptum Nyl. (Thelocarpaceae, Ascomycota), a little known ephemeral lichen of biological soil crust...

Томин М.П. Определитель корковых лишайников Европейской части СССР (кроме Крайнего Севера и Крыма). - Минск: из-во АН БССР, 1956. - 533 с.

BIELCZYK U., JEJDRZEJCZYK-KORYCIN`SKSA M., KISZKA J. Lichens of abandoned zinc-lead mines // Acta Mycologica. - 2009. - Vol. 44, N 2. - P. 139-149.

Gilbert O.L., Purvis O.W. Sarcosagium A. Massal. (1856) // In: The Lichens of Great Britain and Ireland (Smith C.W. et al., eds). - London, 2009. - P. 832.

NAvarro-Rosinés P., RouX C., Bellemère A. Thelocarpella gordensis gen. et sp. nov. (Ascomycetes lichenisati, Acarosporaceae) // Canadian Journal of Botany. - 1999. - Vol. 77, N 6. - P. 835-842.

NYLANDER W. Addenda nova ad lichenographicum europaeum // Flora. - 1886. - Vol. 69. - P. 461-466.

Orange A., Watson M.F., James P.W., Moore D.M. Thelocarpon Nyl. (1853) / In: The Lichens of Great Britain and Ireland (Smith C.W. et al., eds). - London, 2009. - P. 884-888.

Rose, F. James P.W., Orange A. Thelopsis Nyl. (1855) / In: The Lichens of Great Britain and Ireland (Smith C.W. et al., eds). - London, 2009. - P. 889-891.

Smith C. W., Aptroot A., Coppins B. J., Fletcher A., Gilbert O. L., James P. W., Wolseley P. A. (ed.). The Lichens of Great Britain and Ireland, 2009. -1046 p.

VAN DEN BOOM, P.P.G. Some interesting records of lichens and lichenicolous fungi from The Netherlands IV // Österreichische Zeitschrift für Pilzkunde. - 2000. - Vol. 9. - P. 141-145.

Рекомендує до друку

Отримано 29.11.2010 p.

М.Ф. Бойко

Адреси авторів:

О.С. Ходосовиев, Г.О. Наумович

Херсонський державний університет

вул. 40 років Жовтня, 27

м. Херсон, 73000

Украӥна

e-mail: khodosovtsev@ksu.ks.ua

О.С. Вондракова

Iнcmumym cmeny PAH

Вул. Піонерська, 11

Оренбург, 460000

Російська Федераиія

e-mail:mer.os@mail.ru

\section{Я. Вондрак}

Кафедра ботаніки наукового факультету,

Університет Південної Богемї

Вул. Бранісловська, 31

М. Чеське Будейовіце, CZ-37005,

Чеська Республіка

e-mail:j.vondrak@seznam.cz
Author's addresses:

A. Ye. Khodosovtsev and A.O. Naumovich

Kherson State University

27, 40 Rokiv Zhovtnya str.

Kherson 73000

Ukraine

e-mail: khodosovtsev@ksu.ks.ua

O.S. Vondrakova

Institute of Steppe RAN

11, Pionerskaya str.

Orenburg 460000

Russia

e-mail:mer.os@mail.ru

J. Vondrák

Department of Botany,

Faculty of Science,

University of South Bohemia

Branišovská 31 ,

CZ-37005,

České Budějovice,

Czech Republic

e-mail:j.vondrak@seznam.cz 